\title{
Alternate Strip Clearcutting in Upland Black Spruce
}

\author{
The Nipigon Workshop, June 24 and 25, 1986
}

Nine presentations were given at the workshop, covering the main areas of concern in determining the biological and economic effectiveness of strip cutting as a system for harvesting and regenerating upland black spruce forests on shallow-soil sites in northern Ontario. Eight of those presentations have been revised following peer review and four of the papers appear in this issue of The Forestry Chronicle, the remaining four will appear in a subsequent issue.

The workshop itself was sponsored by the Great Lakes Forestry Centre of the Canadian Forestry Service, the Ontario Ministry of Natural Resources and Domtar Forest Products.

\section{Alternate Strip Clearcutting in Upland Black Spruce I. An Introduction}

\author{
by
}

Fred C. Robinson ${ }^{1}$

\begin{abstract}
This paper is the introduction to a workshop on the subject of alternate strip clearcutting in upland black spruce. The workshop, held on 24 and 25 June 1986 , represents a 10 -year review of a project that includes studies of economics, regeneration, environmental impacts, and planning and implementation. A historical background to the project and a list of papers presented are given. A set of general recommendations, arising from deliberations and discussions by workshop participants, is presented. In the current issue of The Forestry Chronicle, this introduction and three of the workshop papers are published. A final set of papers from the workshop will be published in a subsequent issue.
\end{abstract}

\section{Résumé}

Cet article est l'introduction à un atelier sur la coupe rase en bandes alternées de l'épinette noire des hautes terres. Cet atelier qui a eu lieu les 24 et 25 juin 1986 fait la rétrospective décennale d'un projet qui comprend l'étude des facteurs économiques, de la régénération, des incidences environnementales ainsi que de la planification et de la mise en oeuvre. L'historique du projet ainsi qu'une liste de communications sont présentés, de même qu'une série de recommandations générales découlant des délibérations et des discussions des participants. La présente livraison du journal comprend, outre la présente introduction, trois des communications présentées à l'atelier. Les autres communications seront publiées dans un numéro ultérieur.

\section{Introduction}

The technique of strip clearcutting to regenerate black spruce has been in sporadic use for many years in Ontario (Losee 1966, Hughes 1967, Marek 1975, Fraser et al. 1976, Haavisto 1979, Jeglum 1980). The technique is usually a twocut system in which alternate strips are cut first (Fig. 1), and after these have been naturally regenerated from seed, the remaining strips are removed in a second and final cut. (Rarely, three- or four-cut systems are used, but these are not discussed here.) The technique was introduced by foresters with a European background who believed that it was possible to achieve regeneration by using the natural regenerative capacities of the forest, and that this would be more economical than conventional planting of nursery stock. The technique is usually applied on sites with low productivity and/or poor accessibility, which do not warrant the high

1217 Elm St., Stayner, Ontario LOM 1S0 expense of planting. Another important reason for strip cutting is to achieve regeneration on sites that are 'fragile' (susceptible to damage) or difficult to regenerate by planting, such as shallow soils over bedrock, rough terrain, and peatlands (Robinson 1974, Marek 1975).

In Ontario, usually the first- and second-cut (leave) strips are the same width, from 40 to $80 \mathrm{~m}$ ( 2 to 4 chains) wide, but occasionally they are up to $100 \mathrm{~m}$ wide (Robinson 1974). Strip length varies depending on road layout and operational practices but has been on the order of 180 to $300 \mathrm{~m}$. Frequently the first cut strips facing either side of an access road are staggered so that the piles of trees placed by the skidders at the heads of the strips are spread out along the road (Fig. 1).

The first strip is normally site prepared soon after harvesting to provide sufficient receptive seedbed to achieve acceptable levels of regeneration (Robinson 1974). The last strip is cut from 2 to 10 years later, when the manager is 